\title{
A Hybrid Model to Quantify the Impact of Climate Change on Agriculture in Godavari Basin, India
}

\author{
K. Palanisami \\ International Water Management Institute, Hyderabad 502324, India \\ E-mail: k.palanisami@cgiar.org \\ C. R. Ranganathan \\ Tamil Nadu Agricultural University, Coimbatore 641003, India \\ E-mail: crr_nathan@yahoo.co.in \\ K. R. Kakumanu \\ International Water Management Institute, Hyderabad 502324, India \\ E-mail: k.krishnareddy@cgiar.org \\ Udaya Sekhar Nagothu \\ Bioforsk, Institute for Agricultural and Environmental Research \\ FA Dahls vei 20, NO-1432 Ås, Norway \\ E-mail: Nagothu.UdayaSekhar@bioforsk.no
}

Received: October 19, $2011 \quad$ Accepted: October 31, $2011 \quad$ Published: December 31, 2011
doi:10.5539/eer.v1n1p32ＵRL: http://dx.doi.org/10.5539/eer.v1n1p32

\begin{abstract}
A hybrid model incorporating the econometric and programming models was developed to quantify the impact of climate change on agriculture in Godavari basin, India. The Just and Pope production function was used to estimate the mean yield of crops and the variance associated with the mean yield and using the estimated yield, the multiple goal programming model was used to optimize the land and water use under mid and end century climate change scenarios. The results indicated that rice production will reduce during mid and end-century periods by $16 \%$ and $36 \%$ respectively and by incorporating the water and labour saving technologies in the crop production, the reduction in rice production will be eliminated during mid-century and it will be only $19 \%$ during end-century period. The overall water saving will be about $20 \%$ due to the adoption of these technologies. Technology up-scaling programs are suggested. Areas for future research are also indicated.
\end{abstract}

Keywords: Godavari river basin, Optimisation, Sri Ram Sagar Project, Climate change, Water use

\section{Introduction}

Climate change is a reality now. Agriculture is the most affected sector because two of its primary inputs, precipitation and temperature. The inter-annual and long-term variability of monsoon rainfall have indicated that variation in rainfall for the subcontinent is statistically significant (Thapliyal and Kulshrestha 1991; Srivastava et al., 1992). Hence, monsoon rainfall is considered as the important climatic phenomenon in the Indian subcontinent and the adjoining Asian and African regions. On the other hand several authors have also acknowledged that there is an increasing trend in surface temperature, with decreasing trends in rainfall (Hingane et al., 1985; Srivastava et al., 1992; Rupa Kumar et al., 1994; Pant et al., 1999; Singh and Sontakke 2002; Kripalani et al., 1996; Palanisami et al., 2009a and Palanisami, et al., 2009b). It has been recognised that such climate change affects not only yield, but also its variability (Chen et al., 2004; Isik \& Devadoss 2006; Ranganathan, 2009; Barnwal and Kotani, 2010). Hence, while quantifying the impact of climate change it is necessary that these two quantities are jointly estimated. Many previous studies on quantifying impact of climate 
change employ regression techniques and concentrated on the estimation of average productivity only. Little attention was given to optimal land allocation to competing crops with climate change induced productivities. The problem becomes more important in the context of gradual decline in available land area for agriculture due to urbanization.

This paper focuses on estimating average yield and variability in yield of three important crops, namely, paddy, maize and groundnut grown in 4 districts of Sri Ram Sagar Project in Godavari basin, by applying an econometric technique. Further, the climate change induced productivities are used to derive optimum crop area to maximize food production. It is expected that the results may be useful for policy planners in optimum land use planning in the context of climate change.

The main policy relevance of quantifying the impact of climate variables on crop production is for formulating optimal allocations of agricultural land among crops and for defining a crop production mix. It seems this aspect has not been studied in depth so far. Optimal allocation of land area in the light of climate change will definitely help to use the natural resources in a judicious way. The impact of climate change is reflected in change in the productivity of the crops. These projected yields will be used to estimate maximum possible production in different climate change scenarios by formulating suitable optimization models. It will help for optimal land use planning and allocation. Ranganathan, 2009 studied not only the mean yield and variability in yield due to climatic change, but also formulated optimum land use planning using climate change induced productivities. He analysed panel data for 30 years on 9 important crops grown in Tamil Nadu State, India using Just-Pope production function. The estimated mean yields which reflect the effect of climate change were then used for optimum land use planning. He applied multi-goal linear programming for optimum land use planning.

The objectives of the present study are two fold: i) Studying the impact of climate change scenarios on the mean and variability in yield of three important crops, viz., rice, maize and groundnut that are grown in 4 districts of Sri Ram Sagar Project, and ii) To formulate land and water use planning options utilizing climate change induced productivities of crops and resource availability.

\section{Methodology}

In the present study, we focus on the yield and its variability in the context of climate change. Following Isik and Devadoss 2006, we assume that the relation between yield (also known as yield or production per hectare) $y_{i t}$ of a crop at district $i$ during year $t$ and the climatic variables $x_{i t}$ viz., precipitation and temperature is given by the Just-Pope stochastic production function (Just and Pope, 1978).

$$
y_{i t}=f\left(x_{i t} ; \beta\right)+\omega_{i t} h\left(x_{i t} ; \delta\right)^{0.5}
$$

Where $\omega_{i t}$ is the stochastic term with mean zero and variance $\sigma^{2}$ and $\beta$ and $\delta$ are the production function parameters to be estimated using historical data. The independent variables $\left(x_{i t}\right)$ used for the estimations include a constant, annual precipitation $(\mathrm{P})$, temperature $(\mathrm{T})$, trend $(\mathrm{t})$ and 3 district dummy variables. The expected crop yield is given by $E\left(y_{i t}\right)=f\left(x_{i t} ; \beta\right)$ and crop variability is given by $V\left(y_{i t}\right)=\sigma_{\omega}^{2} h\left(x_{i t} ; \delta\right)$. Hence the functions $f\left(x_{i t} ; \beta\right)$ and $h\left(x_{i t} ; \delta\right)$ are called mean and variance functions respectively.

Estimation of the above production function can be considered as estimation with heteroscedastic errors as in the following equation (Saha et al., 1997; Kumbhakar, 1997)

$$
y_{i t}=f\left(x_{i t} ; \beta\right)+u_{i t}
$$

Where $u_{i t}=\omega_{i t} h\left(x_{i t} ; \beta\right)^{0.5}$ with $E\left(u_{i t}\right)=0$ and $\operatorname{Var}\left(u_{i t}\right)=\sigma^{2} h\left(x_{i t} ; \delta\right)$. There are two approaches suggested in many studies to estimate the mean and variance functions of the Just-Pope production function. They can be estimated using feasible generalized least squares or the maximum likelihood method. For example, Barnwal and Kotani, 2010 applied the first method. However, Saha et al., 1997 have shown that the estimators under the maximum likelihood method are consistent and more efficient than the feasible generalized least squares method. Hence in our study maximum likelihood method has been used. Following Ranganathan 2009 and Isik and Devadoss 2006, the following quadratic form is assumed for the mean function:

$$
f\left(x_{i t} ; \beta, d\right)=\beta_{0}+\beta_{1} P+\beta_{2} T+\beta_{3} t+\beta_{4} P^{2}+\beta_{5} T^{2}+\beta_{6} P T+\sum_{i=1}^{i=3} d_{i} D_{i}
$$


Where $\mathrm{D}_{\mathrm{i}}, \mathrm{i}=1,2,3$ are the district dummy variables taking values 1 and 0 . The variance function $\sigma_{\omega}^{2} h\left(x_{i t} ; \delta, \eta\right)$ with $\sigma_{\omega}^{2}=1$ was assumed to have exponential form

$$
h\left(x_{i t} ; \delta, \eta\right)=\exp \left(\delta x_{i t}+\eta D\right)=\exp \left(\delta_{0}+\delta_{1} P+\delta_{2} T+\delta_{3} t+\sum_{i=1}^{i=3} \eta_{i} D_{i}\right)
$$

This form of the variance function is due to (Harvey, 1976) and subsequently employed by several studies (Isik and Devadoss 2006, Isik and Khanna 2003, Asche and Tveteras 1999). The main advantage of this form is that it ensures positive output variance. Another advantage is that the riskiness of an input variable can be easily derived from the sign of the coefficient of that variable in the function. For example, with the above functional form, it can be easily checked that $\frac{\partial h}{\partial P}=\delta_{1} h$. Since the variance function $h$ is always positive, precipitation will be risk increasing if $\delta_{1}>0$ and it will be risk decreasing if $\delta_{1}<0$.

The mean function can be used to study the maximum possible yield, minimum possible yield variance and also impact of climate change on crop yield. Assuming that precipitation and temperature vary and technology is held at current level, the first order conditions for maximum yield are

$$
\begin{aligned}
& \frac{\partial f}{\partial P}=\beta_{1}+2 \beta_{4} P+\beta_{6} T=0 \\
& \frac{\partial f}{\partial T}=\beta_{2}+2 \beta_{5} T+\beta_{6} P=0
\end{aligned}
$$

and the second order conditions are given by

$$
\begin{gathered}
\frac{\partial^{2} f}{\partial P^{2}}=2 \beta_{4}<0 \\
\frac{\partial^{2} f}{\partial T^{2}}=2 \beta_{5}<0 \\
\left|\begin{array}{cc}
\frac{\partial^{2} f}{\partial P^{2}} & \frac{\partial^{2} f}{\partial P \partial T} \\
\frac{\partial^{2} f}{\partial T \partial P} & \frac{\partial^{2} f}{\partial^{2} T}
\end{array}\right|=4 \beta_{4} \beta_{5}-\beta_{6}^{2}>0
\end{gathered}
$$

Solving equations 4(a) and 4(b) we obtain the levels of precipitation and temperature for which yield is maximum.

However, more accurate region specific predictions for changes in temperature and rainfall are needed to capture the impact of climate change. Gosain and Sandhya Rao, 2011 have applied data from Providing Regional Climates for Impact Studies (PRECIS), Regional Circulation Model (RCM) for projecting climate changes in Godavari basin. PRECIS is the Hadley Centre portable regional climate model, developed to run on a PC with a grid resolution of $0.44^{\circ} \times 0.44^{\circ}$. As pointed out by them PRECIS captures important regional information on summer monsoon rainfall missing in its parent GCM simulations. The changes in temperature and precipitation (from base line period, 1960-1990) predicted for mid-century and end-century (Gosain and Sandhya Rao, 2011) were used in getting the projected change in temperature and precipitation for the Kharif and Rabi season in the study region (Table 1).

Based on these changes, two scenarios are formulated, one for the mid-century and the other one for end-century. The mid-century scenario for Kharif season is an increase of $1.93^{\circ} \mathrm{C}$ and an overall increase of $13.6 \%$ in precipitation. This scenario is denoted by $1.93^{\circ} \mathrm{C} / 13.6 \%$ and for the Rabi season the scenario is $2.22^{\circ} \mathrm{C} / 13.6 \%$. Similarly for the end century the scenarios for Kharif and Rabi are $4.03^{\circ} \mathrm{C} / 17.8 \%$ and $4.28^{\circ} \mathrm{C} / 17.8 \%$. It should be noted that in all these scenarios only the annual change in precipitation (and not seasonal changes) is considered. The reason is annual precipitation reflects inter-seasonal water accumulation. These predicted changes are used in the mean and variance functions (3) and (4) to predict the climate change induced average yield and variability in yield. 


\subsection{Estimation of the parameters}

Under the assumption that $\omega_{i t} \sim N(0,1)$ the likelihood function is given by

$$
L=\left[\frac{1}{2 \pi}\right]^{N / 2} \prod_{t=1}^{T} \prod_{i=1}^{R}\left[\frac{1}{h\left(x_{i t} ; \delta\right)}\right]^{1 / 2} \exp \left[-\left\{y_{i t}-f\left(x_{i t} ; \beta\right)\right\}^{2} / 2 h\left(x_{i t} ; \delta\right)\right]
$$

Where $\mathrm{R}$ is the number of districts and $\mathrm{T}$ is the number of time periods and $\mathrm{N}=\mathrm{RT}$. So the log likelihood function is given by

$$
\ln L=-\frac{1}{2}\left[N \ln (2 \pi)+\sum_{t=1}^{T} \sum_{i=1}^{R} \ln \left(h\left(x_{i t} ; \delta\right)\right)+\sum_{t=1}^{T} \sum_{i=1}^{R} \frac{\left\{y_{i t}-f\left(x_{i t} ; \beta\right)\right\}^{2}}{h\left(x_{i t} ; \delta\right)}\right]
$$

Which has to be maximised to estimate the parameter vectors $\beta$ and $\delta$. STATA software package has inbuilt $m l$ command and it was used to maximise the log likelihood function.

\subsection{Study area, data and variables}

The Sri Ram Sagar Project (SRSP) in Godavari River basin was selected for the analysis. The SRSP covers 4 neighbouring districts viz., Adilabad, Karimnagar, Nizamabad and Warangal. The project is located at Nizamabad and it augments the irrigation needs of these districts besides providing drinking water to Warangal town. The crop data for the present study consisted of 39 years (1970 to 2008) panel data on yield of three important crops, viz., rice, maize and groundnut. The data were collected from various sources, publications and websites. The yield data for the crops were collected from Season and Crop Reports of Andhra Pradesh and also from the website $w w w$.andhrapradeshstat.com. The unit for yield is production in kgs. per hectare of crop area. The climate variables were annual precipitation and average seasonal temperature. Meteorological data were collected from various publications and also from the website www.indiawaterportal.org. The precipitation data are the time series of the total precipitation within a year, that is, annual precipitation and it reflects both precipitation falling directly on a crop and inter-seasonal water accumulation within a year (Isik and Devadoss, 2006). The temperature data is the average temperature observed over the Kharif (June to November) and Rabi (December to April) seasons.

\section{Results and Discussion}

\subsection{Just and Pope function}

Separate Just and Pope Functions were fitted for each crop and for each season by maximizing the log likelihood function given in equation (7). The results for each crop are discussed below.

a) Rice

Rice is the most important food crop for people of South India and Andhra Pradesh's share in rice production in the country is $12.75 \%$. It is grown in most of the districts of Andhra Pradesh during both Kharif and Rabi seasons. Following (Barnwal and Kotani, 2010), for the purpose of our study, Kharif season is from June to November and Rabi season is from December to April. The yield has an increasing trend in both the seasons. Further, during both seasons, in general, yield of Karminagar and Nizamabad districts are higher than the other two districts.

Table 2 provides a summary statistics of rice yield, precipitation and temperature at the 4 districts (average for 39 years, (1970 to 2008). The major share of annual precipitation is from Kharif season in all the districts. Temperature during the Kharif season is slightly higher than that of Rabi season.

Table 3 provides the estimated coefficients for the mean function, variance function, standard errors of the coefficients and log-likelihood function. It can be easily checked that most of the coefficients of the climate variables and their square terms are significant for both mean and variance functions. The coefficient of trend is positive and highly significant in the two seasons showing the technological advancement in rice production in the 4 districts of Andhra Pradesh.

To obtain the maximum possible yield, we make use of equations 4(a) to 5(c). The derived equations are summarized in Table 4. It shows that all the conditions for maximum are satisfied. Solving the equations derived from first order conditions, we obtain the optimum levels of precipitation and temperature. The maximum possible yield levels are obtained by substituting these values in respective mean functions. 
The results show that the optimum annual precipitation level for Kharif rice crop is about $1282 \mathrm{~mm}$ while for the Rabi crop it is $1206 \mathrm{~mm}$. But it can be noted that the normal (average of the last 5 years ending 2008-09) annual precipitation in the 4 districts varies from $994 \mathrm{~mm}$ for Warangal to $1157 \mathrm{~mm}$ for Adilabad (GoAP, 2010). Thus the rainfall is below the optimum levels in all the districts. As far as temperature is concerned, the optimum temperatures during the two seasons are $25.5^{\circ} \mathrm{C}$ and $26.9^{\circ} \mathrm{C}$. The expected maximum yield for each district is given in Table 5.

Table 5 gives the impact of climate change on rice production during two seasons under two climate change scenarios. The percentage losses are computed based on normal yield. The normal yield is the average yield during the last 5 years ending 2008-09. For the first climate change scenario, i.e. an increase of $1.93^{\circ} \mathrm{C}$ in temperature and $13.6 \%$ increase in precipitation, the expected loss in yield during Kharif season, varies from $1.9 \%$ to $9.4 \%$. The highest loss corresponds to Warangal district and the lowest to Karimnagar. The standard deviation ranges from $511 \mathrm{kgs}$ to $763 \mathrm{kgs}$. The second climate change scenario produces greater percentage of losses and variability in yield. The percentage loss varies from $22.9 \%$ to $38.3 \%$ and yield in Adilabad and Warangal districts area is expected to suffer maximum losses. A similar conclusion can be drawn for the yield losses and variability for Rabi season also. Figure 1 gives the graphical representation of variability in two seasons under two climate change scenarios. The variability in yield for end-century is more than that for mid-century.

Thus it can be concluded that climate change induces not only loss in yield but also greater variability in yield of rice. This conclusion coincides with the results of (Ranganathan, 2009; Barnwal and Kotani, 2010).

b) Maize

Maize is an important food crop for people of Andhra Pradesh. Table 6 provides a summary of normal area of maize in the study area. The normal area is the average area for 5 years ending 2008-09. Karminagar district has the maximum area under maize during the two seasons with nearly $50 \%$ of the total area. All the 4 districts show increasing trend of yield. As in the case of rice crop, Karminagar and Nizamabad districts outperform the other two districts.

\section{c) Groundnut}

Groundnut is an important oilseed contributing $42 \%$ of the total production of oilseeds. It is cultivated mostly under rain-fed conditions. It accounts for $58.52 \%$ of the total area under oilseeds in Andhra Pradesh. Table 7 provides the normal area under groundnut in the 4 districts.

Trend in groundnut production shows that productivity is increasing over time implying technological advancements. Warangal district during initial years registered higher yield but in the last decade the yield has declined. Nizamabad followed by Karimnagar has higher productivity than all other districts in the later years.

Parameter estimates of the fitted Just-Pope production functions for maize and groundnut are given in Table 8 . As in the case of rice, coefficients of most of the climate variables are significant for the two crops in mean function as well as in variance function. Coefficients of precipitation, temperature, temperature-squarer are significant for maize with temperature having negative effect on the mean yield. For groundnut, temperature has positive significant effect. Trend has positive significant effect on the two crops. Interaction between precipitation and temperature is not significant for the two crops. Since the coefficients of temperature in the variance function for the two crops are positive and significant, temperature is a risk increasing factor for the two crops where increase in temperature results in higher variability in yield.

The levels of climate variables for maximum production were worked out using equations 4(a) to 5(c). It was found that for maize crop the optimal levels of the two variables are respectively $1042.5 \mathrm{~mm}$ and $28.9^{\circ} \mathrm{C}$. For groundnut the corresponding values are $420.3 \mathrm{~mm}$ and $26.86^{\circ} \mathrm{C}$.

Table 9 presents the climate change impact on the two crops. The percentage of loss in yield for maize is small for the first scenario in all the districts. The maximum loss will be about $8 \%$ for Warangal district. Surprisingly, for the scenario $4.1^{\circ} \mathrm{C} / 17.8 \%$, the percentage loss seems to decrease and the maximum loss will be $5.5 \%$ for Nizamabad district. However variability in yield increases by about 10 to $12 \%$. Thus we can conclude that climate change may not have considerable impact on maize yield in the 4 districts.

However impact of climate change on groundnut production will be considerable. For the first scenario, the percentage loss varies from 13.8 to 25.2. Nizamabad district will have maximum loss. The standard deviation in yield ranges from $292 \mathrm{kgs}$ to $383 \mathrm{kgs}$. The second scenario will have more damaging effect with the percentage loss varying from $69 \%$ to $90 \%$ while the standard deviation ranges from $387 \mathrm{kgs}$ to $802 \mathrm{kgs}$. Thus we can conclude that groundnut production will be very much affected by climate change. 
In summary, climate change will have very serious effect on groundnut, moderate effect on rice and negligible effect on maize. Further, stronger climate change will induce higher variability in yield in all the crops.

\subsection{Optimum land use planning}

As already stated, the climate change induced productivities can be used to formulate optimal land and water use planning for the Sri Ram Sagar Project. The following objectives are formulated under multi-goal linear programming optimisation models:

a) Maximizing rice production

b) Maximizing income

c) Minimizing water use

The mathematical formulation of the optimization models is given below.

\begin{tabular}{|c|l|}
\hline Variable & \multicolumn{1}{|c|}{ Explanation } \\
\hline & Area under crop $C$ in district $d$ during season $s$ \\
$x_{s d C}$ & C=Rice, Maize $\ldots$ \\
& $\begin{array}{l}\mathrm{D}=\text { Adilabad, Karimnagar, Nizamabad, Waranagal } \\
\text { S=Kharif, Rabi }\end{array}$ \\
\hline & Yield under crop $C$ in district $d$ during season $s$ \\
& C=Rice, Maize... \\
$y_{s d C}$ & D=Adilabad, Karimnagar, Nizamabad, Waranagal \\
& S=Kharif, Rabi \\
\hline$A_{s C}$ & Area under crop C in season $s$ in all the 4 districts \\
\hline$P_{s C}$ & Production of crop C in season $s$ in all the 4 districts \\
\hline$A C_{s}$ & Total area under cereals in all the 4 districts in season $s$ \\
\hline$w_{s d C}$ & Water required per hectare for crop C in season $s$ in district $d$ \\
\hline
\end{tabular}

\section{Objective: Maximizing rice production}

\section{Season: Kharif}

The predominant crops during this season in SRS Project area are rice and maize.

Maximize rice production: $\sum_{d=1}^{4} x_{s d R} y_{s d R}, s=$ Kharif

Constraints:

1) Total area under rice and maize in Kharif season should not exceed the available crop area $=3,89,300 \mathrm{ha}$

$$
\sum_{d=1}^{4} x_{s d R}+\sum_{d=1}^{4} x_{s d M} \leq A C_{s}, s=\text { Kharif }
$$

2) Total water required for all crops in Kharif in all the 4 districts is less than or equal to total water available $\left(=3110 \mathrm{Mm} \cdot \mathrm{m}^{3}\right)$

$$
\sum_{C} \sum_{d=1}^{4} w_{s d C} x_{s d C} \leq W_{s}, s=\text { Kharif }
$$

3) Total labour required for all crops in Kharif in all the 4 districts is less than or equal to total labour available $(=2,91,97,500$ man days $)$

$$
\sum_{C} \sum_{d=1}^{4} l_{s d C} x_{s d C} \leq L_{s}, s=\text { Kharif }
$$


4) The Normal (average of the last 5 years area) area under rice in Kharif season in the four districts, viz., Adilabad, Karimnagar, Nizamabad and Warangal are approximately in the ratio 1:2.5:1.7:2.5. It is assumed that this ratio of areas will continue. Hence

$$
x_{s A R}: x_{s K R}: x_{s N R}: x_{s W R}=1: 2.5: 1.7: 2.5
$$

The equivalent linear constraints which are included in the model are

$$
\begin{aligned}
& 2.5 x_{s A R}-x_{s K R}=0 \\
& 1.7 x_{s A R}-x_{s N R}=0 \\
& 2.5 x_{s A R}-x_{s W R}=0
\end{aligned}
$$

5) The Normal (average of the last 5 years area) area under maize in Kharif season in the four districts, viz., Adilabad, Karimnagar, Nizamabad and Warangal are approximately in the ratio 1:5.1:2.6:2.4. It is assumed that this ratio of areas will continue. Hence

$$
x_{s A M}: x_{s K M}: x_{S N M}: x_{s W M}=1: 5.1: 2.6: 2.4
$$

The equivalent linear constraints which are included in the model are

$$
\begin{aligned}
& 5.1 x_{s A M}-x_{s K M}=0 \\
& 2.6 x_{s A M}-x_{S N M}=0 \\
& 2.4 x_{s A M}-x_{s W M}=0
\end{aligned}
$$

6) The normal area under maize is about 70,000 ha. It is assumed that at least this much area should be allotted to maize crop.

\section{Season: Rabi}

$$
\sum_{d=1}^{4} x_{s d M} \geq 70000
$$

The predominant crops during this season in SRS Project area are rice and maize.

Maximize rice production: $\sum_{d=1}^{4} x_{s d R} y_{s d R}, s=R a b i$

Constraints:

1) Total area under rice and maize in Kharif season should not exceed the available crop area $=1,80,000 \mathrm{ha}$

$$
\sum_{d=1}^{4} x_{s d R}+\sum_{d=1}^{4} x_{s d M} \leq A C_{s}, s=R a b i
$$

2) Total water required for all crops in Rabi in all the 4 districts is less than or equal to total water available $\left(=1000 \mathrm{~mm} \cdot \mathrm{m}^{3}\right)$

$$
\sum_{C} \sum_{d=1}^{4} w_{s d C} x_{s d C} \leq W_{s}, s=R a b i
$$

3) Total labour required for all crops in Rabi in all the 4 districts is less than or equal to total labour available $(=1350000$ man days $)$

$$
\sum_{C} \sum_{d=1}^{4} l_{s d C} x_{s d C} \leq L_{s}, s=R a b i
$$

4) The Normal (average of the last 5 years area) area under rice in Rabi season in the four districts, viz., Adilabad, Karimnagar, Nizamabad and Warangal are approximately in the ratio 1:11:4.4:5.3. It is assumed that this ratio of areas will continue. Hence 


$$
x_{s A M}: x_{s K M}: x_{S N M}: x_{s W M}=1: 11: 4.4: 5.3
$$

The equivalent linear constraints which are included in the model are

$$
\begin{aligned}
& 11 x_{s A M}-x_{S K M}=0 \\
& 4.4 x_{s A M}-x_{S N M}=0 \\
& 5.3 x_{S A M}-x_{S W M}=0
\end{aligned}
$$

5) The Normal (average of the last 5 years area) area under maize in Rabi season in the four districts, viz., Adilabad, Karimnagar, Nizamabad and Warangal are approximately in the ratio 1:6.3:1.2:3.3. It is assumed that this ratio of areas will continue. Hence

$$
x_{s A M}: x_{s K M}: x_{s N M}: x_{s W M}=1: 6.3: 1.2: 3.3
$$

The equivalent linear constraints which are included in the model are

$$
\begin{aligned}
& 6.3 x_{S A M}-x_{S K M}=0 \\
& 1.2 x_{S A M}-x_{S N M}=0 \\
& 3.3 x_{S A M}-x_{S W M}=0
\end{aligned}
$$

6) The Normal (average of the last 5 years area) area under groundnut in Rabi season in the four districts, viz., Adilabad, Karimnagar, Nizamabad and Warangal are approximately in the ratio 1:3.2:0.5:6.2. It is assumed that this ratio of areas will continue. Hence

$$
x_{s A M}: x_{S K M}: x_{S N M}: x_{s W M}=1: 3.2: 0.5: 6.2
$$

The equivalent linear constraints which are included in the model are

$$
\begin{aligned}
& 3.2 x_{s A M}-x_{S K M}=0 \\
& 0.5 x_{s A M}-x_{S N M}=0 \\
& 6.2 x_{S A M}-x_{s W M}=0
\end{aligned}
$$

7) The normal area under maize in Rabi is about 50,000 ha. It is assumed that at least this much area should be allotted to maize crop.

$$
\sum_{d=1}^{4} x_{s d M} \geq 50000
$$

8) The normal area under groundnut in Rabi is about 11,000 ha. It is assumed that at least this much area should be allotted to groundnut crop.

$$
\sum_{d=1}^{4} x_{s d G} \geq 11000
$$

\section{Objective: Maximizing the net income of the farmer}

a) Season: Kharif

The objective is to maximize the net income of the farmer during Kharif season. That is

Maximize Net Income $\sum_{d=1}^{4} \sum_{C} R_{s d C} y_{s d C}, s=$ Kharif

In addition to the constraints described as in objective I, an additional constraint is included which guarantees that the rice production in Kharif season will not be lower than the maximum level. That is, if $R_{\text {max Kharif }}$ is the maximum rice production, then the new constraint added is 


$$
\sum_{d=1}^{4} x_{s d R} y_{s d R} \geq R_{\text {max Kharif }}
$$

b) Season: Rabi

The objective is to maximize the net income of the farmer during Kharif season. That is

Maximize Net Income $\sum_{d=1}^{4} \sum_{C} R_{s d C} y_{s d C}, s=R a b i$

In addition to the constraints described as in objective I, an additional constraint is included which guarantees that the rice production in Kharif season will not be lower than the maximum level. That is, if $R_{\max R a b i}$ is the maximum rice production, then the new constraint added is

$$
\sum_{d=1}^{4} x_{s d R} y_{s d R} \geq R_{\max R a b i}
$$

In addition to the constraints described as in I, an additional constraint is included which guarantees that the rice production will not be lower than the maximum level.

\section{Objective: Minimizing water use}

\section{a) Season: Kharif}

The objective is to minimize the water use in agriculture. That is

Minimize water use $\sum_{d=1}^{4} \sum_{C} w_{s d C} y_{s d C}, s=$ Kharif

The constraints on water availability and labour are removed and all other constraints that were included for maximizing income are retained. Two new constraints, one for fixing target for rice production and the other one for fixing target for income are added. If $\mathrm{T}$ and $\mathrm{MI}$ are respectively maximum rice production and maximum income MI, the constraints can be written as:

$$
\begin{gathered}
\sum_{d=1}^{4} x_{s d R} y_{s d R} \geq T \\
\sum_{d=1}^{4} \sum_{C} R_{s d C} y_{s d C} \geq M I
\end{gathered}
$$

Thus the model will estimate the required minimum quantity of water that will ensure the target rice production $\mathrm{T}$ and maximum income MI.

b) Season: Rabi

The constraints are same as given for Kharif season.

Optimization for the first two objectives are carried out with 4 different climate change scenarios and 8 different management options that are described in Tables 10 and 11.

The scenario S1 reflects current state of affairs, scenario S2 corresponds to 'near future' status. This scenario assumes $10 \%$ reduction in water availability for agriculture and $5 \%$ reduction in labour availability. The reduction in water availability is based on the assumption that, in spite of increase in precipitation predicted by climate change scenarios, the share for agriculture will be reduced due to increased demand for domestic consumption and industrial use. Similarly labour availability will also reduce due to mechanization. The mid-century scenario is termed as S3. In this scenario, the productivities of the crops derived from Just and Pope functions for the Kharif and Rabi seasons are used. The last scenario, termed as S4, uses the end century predictions of yield levels. The 8 management options are based on promising technologies for rice and maize. For example, SRI is the most recommended technology for rice cultivation and MWM is recommended for maize. 
The third objective seeks to minimize water use in agriculture and at the same time meeting the targets on rice production and income. The target $\mathrm{T} 1$ refers to the current situation. The maximum possible rice production and maximum income achievable under 8 management options are the targets to be met while minimising water usage. For the second target T2, the maximum rice production and income levels when water available and labour are reduced respectively by $10 \%$ and $5 \%$ are used. The same target levels are used in T3 and T4 also wherein the productivity are reduced by climate change.

In this optimization framework, the objectives are first prioritized as stated above. First priority is given for maximum rice production because food security for the society is of primary importance. Next priority is for maximum income as it will ensure better livelihood for the farmers. While running the linear programs to meet the second objective, a new constraint which will ensure that the rice production will be at least equal to the maximum level as dictated by the first objective is met. Thus the results of the first two objectives will ensure maximum food production and better livelihood. The third objective is to minimize water usage in agriculture. This objective is important because, as shown by historical data, the share of water use in agriculture is declining over years due to increased demand for water in other sectors. The results of the first two objectives are incorporated as constraints in meeting the third objective. Thus the results of all the three optimization models will provide a complete framework for optimum land and water use planning to meet triple targets: food availability, better income and minimum water use.

The optimisation models are formulated separately for Kharif and Rabi seasons as the crops grown in the two seasons in the Sri Ram Sagar Project area are different. The optimization is carried out for all the combinations of the scenarios and management options for the first two objectives. In the case of the third objective it was done for all combinations of target levels and management options. In other words the optimization is carried out for 32 combinations of scenario/target and management options for each season. Thus for the complete model, a total of 192 linear programs were solved. The results of the models are discussed briefly below:

\subsection{Climate change and impact of crop production, income and water use-Results of the optimization models}

Current rice production in Kharif season is 5.7 lakh tonnes and it will be 5 lakh tonnes in the near future, (i.e., in the next 20 years). As per the mid-century predictions, the production will be 4.8 lakh tonnes and it will be 3.6 lakh tonnes during the end-century (Figure 2)

Total gross income from crop production during Kharif season at present is Rs 2.9 billions and will reduce to Rs 2.67 billions in the next 20 years. During the mid and end century the gross income will reduce to Rs 2.52 and Rs 2.37 billion respectively (Figure 3)

In order to get the current level of production and gross income, water required is $3868 \mathrm{Mm}^{3}$ and will be 3479 $\mathrm{Mm}^{3}$ in the next 20 years. However during the mid and end century, the water required to maintain the current level of production and gross income will be $3679 \mathrm{Mm}^{3}$ and $4794 \mathrm{Mm}^{3}$ respectively (Figure 4).

Hence it is important to see how the production and income will be maintained in the future using various adaptation strategies. As indicated earlier, water and labour saving technologies will help to minimize the production and income losses due to climate change impacts and will also reduce the burden on water use. It is seen from the optimization results, when the water and labour saving technologies are adopted in the crop production, the current rice production will be 7.1 lakh tonnes (24.5\% increase), 6.4 lakh tonnes (12.2\% increase) in the next 20 years and it will be 6.0 lakh tonnes (5.2\% increase) during mid-century and 4.6 lakh tonnes $(19 \%$ decrease) respectively. The end-century will observe $19 \%$ reduction in rice production compared to $37 \%$ reduction if no technological interventions are made. Thus water management and labour saving technologies will help to address the negative impact of the climate change in rice production in the project area. The same trend is seen in the case of gross income and water use during different periods.

In the Rabi season, current rice production is 1.6 lakh tonnes and it will be 1.4 lakh tonnes in the next 20 years. As per the mid-century prediction, the production will be 1.4 lakh tonnes and it will be 1.1 lakh tonnes during the end-century (Figure 5).

Total gross income from crop production during Rabi season at present is Rs 1.29 billions and will reduce to 1.21 billions in the next 20 years. During the mid and end-century the gross income will reduce to Rs 1.12 and 0.93 billion respectively (Figure 6).

In order to get the current level of production and gross income, water required is $1236 \mathrm{Mm}^{3}$ and will be 1111 $\mathrm{Mm}^{3}$ in the next 20 years. However during the mid and end century, the water required to maintain the current level of production and gross income will be $1177 \mathrm{Mm}^{3}$ and $1442 \mathrm{Mm}^{3}$ respectively (Figure 7). Hence it is 
important to see how the production and income will be maintained in the future using various adaptation strategies.

\section{Discussion}

As indicated earlier, water and labour saving technologies will help to minimize the production and income losses due to climate change impacts and will also reduce the burden on water use. It is seen from the optimization results, when the water and labour saving technologies are adopted in the crop production, the current rice production will be 1.65 lakh tonnes, 1.45 lakh tonnes ( $9 \%$ decrease) in the next 20 years and it will be 1.37 lakh tonnes (14\% decrease) and 1.40 lakh tonnes (12.5\% decrease) respectively during mid and end centuries. The reduction is comparatively small when compared to the situation when no technologies interventions are made to cope up with the climate change impacts. The same trend is seen in the case of gross income and water use during different periods.

In the case of optimizing the water use at the project level, current and near future rice production and income are used to arrive at the optimum water use as they will reflect the actual water use levels in the next 10-20 years. Given the current (target) level of rice production of 7.15 lakh tonnes and income of Rs 3.48 billions, the current water use will be $3868 \mathrm{Mm}^{3}$ and with the water and labour saving technologies, the optimum water use will be $3110 \mathrm{Mm}^{3}$ (19\% reduction in water use). With medium term projection of 6.4 lakh tonnes production and Rs 3.19 billions income, the optimum water use will be $3439 \mathrm{Mm}^{3}$ and $2759 \mathrm{Mm}^{3}$ respectively without and with water and labour saving technologies resulting in a $20 \%$ saving in water use.

Thus the adoption of the water and labour saving technologies help the rice production in the project area. It is observed that in all the cases, the SRI resulted in higher production, gross income and water saving compared to alternate drying and wetting and machine transplanting. Machine transplanting helped the rice production thus releasing the labour to cover additional area under rice. It is understood that in the future, the labour scarcity is expected to reduce the area under rice as it will constraint the transplanting operations. Hence machine transplanting helps to ease the labour scarcity to the extent of $20 \%-25 \%$.

\section{Conclusion}

The optimization model has thus projected that the climate change impact in the long-term basis is projected to reduce the rice production in the project area by $25 \%-30 \%$. The key message is that water is the key constraint in rice production in the long-run and land put under current fallow due to water scarcity will be a key issue to be dealt with. Implementation of various rice water and labour saving technologies will minimize the reduction in rice production between $20 \%-25 \%$ under the medium-term and long-term basis. Hence, simply implementing the water management technologies will address the rice production constraints without making any structural interventions such as construction of new storage structures. Already field level studies in the project area had shown that water saving technologies will have a higher rate of return in rice production systems (Palanisami et al., 2011). The key question is how and what scale, these technologies should be introduced and what kind of institutional and capacity building mechanisms are needed to achieve this.

\section{Recommendations}

- Water management technologies should be piloted in selected locations of the project and based on the success of these technologies, the upscaling mechanisms should be initiated.

- A cluster approach (covering a group of villages in a location) will be more useful in up-scaling the water management technologies and farmers will be free to interact and follow up with the relevant technologies.

- Labour saving technologies such as machine transplanting has proved to increase the rice area and production in all the climate scenarios. Hence given the future labour scarcity in rice production, machine transplanting package should be organized at village level through the involvement of local community. A custom hiring unit can be established in the cluster of villages and farmers can easily forecast their requirement for paddy seedlings and planting in a given time schedule.

- The existing government programs with the agriculture department of the Government of Andhra Pradesh should include the water management technologies in their program.

- Adequate capacity building programs in technology upscaling and mainstreaming should be established. The expertise with the agricultural university research stations should be explored for strengthening the capacity building programs.

\section{Future research}


- There is scope for studying risk minimisation strategies for land use planning in the presence of large uncertainty. It may also be true that certain crops have lower expected yield, but less variance. Minimizing risk, instead of maximising expected yield, may be a wiser strategy in the presence of large uncertainty.

- Inter seasonal storage variability and its impact on crop production and area in the reservoir projects will also be examined in the future research.

- Impact of mixed crops, direct sown rice on water saving and land use planning will also form an important future research agenda.

- Returns to water management strategies will also be analysed as part of the future research agenda.

\section{Acknowledgements}

The authors wish to thank The Ministry of Foreign Affairs, Norway and The Royal Norwegian Embassy New Delhi for sponsoring the study.

\section{References}

Asche, F. and Tveteras, R. (1999). Modeling production risk with a two-step procedure. Journal of Agricultural and Resource Economics, 24, 429-439.

Barnwal, P. and Kotani, K. (2010). Impact of variation in climatic factors on crop yield: A case of rice crop in Andhra Pradesh, India. Economics and Management Series, EMS-2010-17, International University of Japan.

Chen, C. C., McCarl, B. A., and Schimmelpfennig, D. E. (2004). Yield variability as influenced by climate: A statistical investigation. Climatic Change, 66(1-2), 239-261. http://dx.doi.org/10.1023/B:CLIM.0000043159.33816.e5

Gosain, A. K. and Sandhya Rao. (2011). Analysis of climate change scenarios in the Godavari river basin, Draft. Indian Institute of Technology, Delhi.

Harvey, A. C. (1976). Estimating regression models with multiplicative heteroscedasticity. Econometrica, 44, 461-465. http://dx.doi.org/10.2307/1913974

Hingane, L. S., Rupa Kumar, K and Ramana Murthy, B. H. (1985). Long-term trends of surface air temperature in India. International Journal of Climatology, 5, 521-528. http://dx.doi.org/10.1002/joc.3370050505

Isik, M. and Devadoss, S. (2006). An analysis of the impact of climate changes on crop yields and yield variability. Applied Economics, 38, 835-844. http://dx.doi.org/10.1080/00036840500193682

Isik, M. and Khanna, M. (2003). Stochastic technology, risk preferences and adoption of site-specific technologies. American Journal of Agricultural Economics, 85, 305-317. http://dx.doi.org/10.1111/1467-8276.00121

Just, R. E. and Pope, R. D. (1978). Stochastic specification of production functions and economic implications. Journal of Econometrics, 7, 67-86. http://dx.doi.org/10.1016/0304-4076(78)90006-4

Kripalani, R. H., Inamdar, S. R. and Sontakke, N. A. (1996). Rainfall variability over Bangladesh and Nepal: Comparison and connection with features over India. International Journal of Climatology, 16, 689-703. http://dx.doi.org/10.1002/(SICI)1097-0088(199606)16:6<689::AID-JOC36>3.0.CO;2-K

Kumbhakar, S. C. (1997). Efficiency estimation with heteroscedasticity in a panel data model. Applied Economics, 29, 379-386. http://dx.doi.org/10.1080/000368497327164

Palanisami, K., Ranganathan, C. R., Senthinathan, S. and Aggarwal, P. K. (2009a). Impact of climate change on crop production in Tamilnadu using Ricardian Approach in P.K.Aggarwal (ed.) Global Climate Change and Indian Agriculture. Indian Council of Agricultural Research, New Delhi, 19-23.

Palanisami, K., Ranganathan, C. R., Senthilnathan, S. and Chieko Umetsu. (2009b). Diversification of agriculture in coastal districts of Tamil Nadu - A spatio-temporal analysis, Inter-University Research Institute Corporation, National Institutes for the Humanities. Research Institute for Humanity and Nature, Japan, 130-137.

Palanisami, K., Kakumanu, K. R., Suresh Kumar, D., Chellamuthu, S., Chandrasekaran, B., Ranganathan, C. R. and Giordani Mark (2011). Do investments in water management research pay? Evidences from Tamil Nadu, India. Water Policy, Paper accepted for publication in October 2011.

Pant, G. B., Rupa Kumar, K. and Borgaonkar, H. P. (1999). The Himalayan environment (eds Dash, S. K. and Bahadur, J.), New Age International (P) Ltd, New Delhi, 172-184.

Ranganathan, C. R. (2009). Quantifying the impact of climatic change on yields and yield variability of major crops and optimal land allocation for maximizing food production in different agro-climatic zones of Tamil 
Nadu, India: An Econometric Approach, Working paper. Research Institute for Humanity and Nature, Kyoto, Japan.

Rupa Kumar, K., Krishna Kumar, K. and Pant, G. B. (1994). Diurnal asymmetry of surface temperature trends over India. Geophysical Research Letter, 21, 677-680. http://dx.doi.org/10.1029/94GL00007

Saha, A., Havenner, A. and Talpaz, H. (1997). Stochastic production function estimation: small sample properties of ML versus FGLS. Applied Economics, 29, 459-469. http://dx.doi.org/10.1080/000368497326958

Singh, N. and Sontakke, N. A. (2002). On climate fluctuations and environmental changes of the Indo-Gangetic plains, India. Climatic Change, 52, 287-313. http://dx.doi.org/10.1023/A:1013772505484

Srivastava, H. N., Dewan, B. N., Dikshit, S. K., Rao, G. S. P., Singh S. S and Rao, K. R. (1992). Decadal trends in climate over India, Mausam, 43, 7-20.

Thapliyal, V. and Kulshrestha, S. M. (1991). Climate change and trends over India. Mausam, 42, 333-338.

Table 1. Projected changes in Climatic Variables

\begin{tabular}{|l|c|c|c|}
\hline \multicolumn{4}{|c|}{ Change in Mean Daily Average temperature $\left({ }^{\circ} \mathrm{C}\right)$} \\
\hline & Kharif (June to November) & Rabi (December to April) \\
\hline Change from Baseline to Mid-Century & 1.93 & 2.22 \\
\hline Change from Baseline to End Century & 4.03 & 4.28 \\
\hline \multicolumn{4}{|c|}{ Change in Mean Precipitation (\%) } \\
\hline & $\begin{array}{c}\text { Kharif } \\
\text { (June to November) }\end{array}$ & $\begin{array}{c}\text { Rabi } \\
\text { (December to April) }\end{array}$ & Overall \\
\hline Change from Baseline to Mid-Century & 12.5 & 17.6 & 13.6 \\
\hline Change from Baseline to End Century & 13.0 & 53.4 & 17.8 \\
\hline
\end{tabular}

Source: Authors calculations based on figures given in Tables land 2 of Gosain and Sandhya Rao (2011).

Table 2. Summary statistics of yield of rice and climate variables

\begin{tabular}{|l|l|l|l|l|l|l|}
\hline \multirow{2}{*}{ District } & \multicolumn{3}{|c|}{ Kharif season (June to November) } & \multicolumn{3}{c|}{ Rabi season (December to April) } \\
\cline { 2 - 7 } & $\begin{array}{l}\text { Yield } \\
(\mathrm{kgs} / \mathrm{ha})\end{array}$ & $\begin{array}{l}\text { Precipitation } \\
(\mathrm{mm})\end{array}$ & $\begin{array}{l}\text { Temperature } \\
\left({ }^{\circ} \mathrm{C}\right)\end{array}$ & $\begin{array}{l}\text { Yield } \\
(\mathrm{kgs} / \mathrm{ha})\end{array}$ & $\begin{array}{l}\text { Precipitation } \\
(\mathrm{mm})\end{array}$ & $\begin{array}{l}\text { Temperature } \\
\left({ }^{\circ} \mathrm{C}\right)\end{array}$ \\
\hline Adilabad & 1543 & 941.4 & 27.3 & 2179 & 43.1 & 26.5 \\
\hline Karimnagar & 2437 & 905.8 & 27.0 & 2523 & 56.1 & 26.2 \\
\hline Nizamabad & 2241 & 888.2 & 26.7 & 2242 & 47.0 & 26.5 \\
\hline Warangal & 2167 & 817.8 & 27.8 & 2039 & 50.5 & 26.7 \\
\hline
\end{tabular}


Table 3. Just and Pope production function for Rice: Parameter estimates

\begin{tabular}{|c|c|c|c|c|}
\hline Variables & \multicolumn{2}{|r|}{ Kharif } & \multicolumn{2}{|r|}{ Rabi } \\
\hline Mean Yield & Coefficient & Std.Error & Coefficient & Std.Error \\
\hline Precipitation (R)(in mm) & $7.2104^{* *}$ & 3.5083 & $2.4397 * *$ & 0.995 \\
\hline Temperature (T)(in oC) & $2245.9150^{* *}$ & 1015.6600 & $2284.363 * *$ & 1098.4 \\
\hline Trend(year) & $42.4363^{* * *}$ & 2.3439 & $42.7376^{* * *}$ & 2.88 \\
\hline $\mathrm{R} 2$ & $-0.0013^{* * *}$ & 0.0003 & $-0.0016 * * *$ & 0.00038 \\
\hline $\mathrm{T} 2$ & -40.1724 & 50.3485 & -43.6677 & 57.13 \\
\hline $\mathrm{R}^{*} \mathrm{~T}$ & -0.1519 & 0.1944 & 0.0528 & 0.19 \\
\hline Adilabad & -710.6665 & 59.2652 & $159.4246^{* *}$ & 79.32 \\
\hline Karimnagar & $119.0369^{* *}$ & 62.4787 & $427.0203 * * *$ & 67.17 \\
\hline Nizamabad & 5.2939 & 95.3290 & 215.0166 & 74.92 \\
\hline Constant & -31671.7 & 39543.3500 & -30787.6 & 42010.98 \\
\hline \multicolumn{5}{|l|}{ Variability in Yield } \\
\hline Precipitation $(\mathrm{R})$ & $-0.0014^{* *}$ & 0.0006 & -0.0004 & 0.0007 \\
\hline Temperature $(\mathrm{T})$ & $0.6296^{* *}$ & 0.2775 & 0.2830 & 0.246 \\
\hline Trend & $0.0267^{* *}$ & 0.0126 & $0.0315^{* *}$ & 0.0138 \\
\hline Adilabad & $1.0743^{* *}$ & 0.3636 & -0.3060 & 0.402 \\
\hline Karimnagar & $0.8547^{* *}$ & 0.4534 & $-0.6833^{*}$ & 0.41 \\
\hline Nizamabad & $1.9225^{* * *}$ & 0.4638 & -0.2294 & 0.37 \\
\hline Constant & -6.1009 & 7.6631 & 3.8732 & 6.69 \\
\hline Likelihood Fun. & -1096.8 & & -1106.4 & \\
\hline
\end{tabular}

*Significant at $10 \%$ level; ** Significant at $5 \%$ level; $* * *$ Significant at $1 \%$ level

Table 4. Summary of optimization of mean function for rice

\begin{tabular}{|c|c|c|c|c|c|c|}
\hline Season & First order conditions & $\frac{\partial^{2} f}{\partial P^{2}}$ & $\frac{\partial^{2} f}{\partial T^{2}}$ & $\frac{\partial^{2} f}{\partial P^{2}} \frac{\partial^{2} f}{\partial T^{2}}-\left(\frac{\partial^{2} f}{\partial P \partial T}\right)^{2}$ & $\begin{array}{c}\text { Optimum } \\
\text { level of } \\
\text { precipitation }\end{array}$ & $\begin{array}{c}\text { Optimum } \\
\text { level of } \\
\text { temperature }\end{array}$ \\
\hline Kharif & $\begin{array}{l}0.152 \mathrm{P}+80.345 \mathrm{~T}=2245.92 \\
0.0026 \mathrm{R}+0.152 \mathrm{~T}=7.21\end{array}$ & -0.0026 & -80.345 & 0.186 & $1281.67 \mathrm{~mm}$ & $25.53^{\circ} \mathrm{C}$ \\
\hline Rabi & $\begin{array}{l}0.053 \mathrm{P}-87.335 \mathrm{~T}=-2284.36 \\
-0.0032 \mathrm{R}+0.0528 \mathrm{~T}=-2.44\end{array}$ & -0.0032 & -87.335 & 0.277 & $1205.90 \mathrm{~mm}$ & $26.89^{\circ} \mathrm{C}$ \\
\hline
\end{tabular}


Table 5. Impact of climate change on rice yield in the two seasons in Godavari basin $(\mathrm{kg} / \mathrm{ha})$

\begin{tabular}{|c|c|c|c|c|c|c|c|}
\hline Season & $\begin{array}{l}\text { Climate } \\
\text { change }\end{array}$ & & $\begin{array}{l}\text { Adilabad } \\
\text { district }\end{array}$ & $\begin{array}{l}\text { Karimnaga } \\
\mathrm{r} \text { district }\end{array}$ & $\begin{array}{l}\text { Nizamabad } \\
\text { district }\end{array}$ & $\begin{array}{l}\text { Waranga } \\
1 \text { district }\end{array}$ & $\begin{array}{l}\text { All } \\
\text { districts }\end{array}$ \\
\hline \multirow{8}{*}{ Kharif } & \multirow{5}{*}{$\begin{array}{l}\text { Mid-Century } \\
1.93^{\circ} \mathrm{C} / 13.6 \%\end{array}$} & Normal Yield & 2262 & 3115 & 3226 & 3009 & 2972 \\
\hline & & Max-Yield & 2616 & 3445 & 3332 & 3326 & 3180 \\
\hline & & MC-Predicted Yield & 2140 & 3056 & 3028 & 2726 & 2747 \\
\hline & & $\begin{array}{l}\% \text { Loss } \\
\text { (base-Normal Yield) }\end{array}$ & 5.4 & 1.9 & 6.1 & 9.4 & 7.6 \\
\hline & & Standard Deviation & 616 & 511 & 763 & 455 & 575 \\
\hline & \multirow{3}{*}{$\begin{array}{l}\text { End-Century } \\
4.03^{\circ} \mathrm{C} / 17.8 \%\end{array}$} & EC-Predicted Yield & 1395 & 2401 & 2438 & 1989 & 2065 \\
\hline & & $\begin{array}{l}\% \text { Loss } \\
\text { (base-Normal Yield) }\end{array}$ & 38.3 & 22.9 & 24.4 & 33.9 & 30.5 \\
\hline & & Standard Deviation & 1160 & 964 & 1439 & 860 & 1086 \\
\hline \multirow{8}{*}{ Rabi } & \multirow{5}{*}{$\begin{array}{l}\text { Mid-Century } \\
2.22^{\circ} \mathrm{C} / 13.6 \%\end{array}$} & Normal Yield & 2460 & 3338 & 3214 & 2929 & 2985 \\
\hline & & Max-Yield & 2544 & 3374 & 3260 & 3255 & 3108 \\
\hline & & MC-Predicted Yield & 2248 & 3129 & 2975 & 2882 & 2814 \\
\hline & & $\begin{array}{l}\text { \% Loss } \\
\text { (base-Normal Yield) }\end{array}$ & 8.6 & 6.2 & 7.4 & 1.6 & 5.7 \\
\hline & & Standard Deviation & 536 & 458 & 828 & 371 & 523 \\
\hline & \multirow{3}{*}{$\begin{array}{l}\text { End-Century } \\
4.28^{\circ} \mathrm{C} / 17.8 \%\end{array}$} & EC-Predicted Yield & 1596 & 2550 & 2355 & 2274 & 2200 \\
\hline & & $\begin{array}{l}\text { \% Loss } \\
\text { (base-Normal Yield) }\end{array}$ & 35.1 & 23.6 & 26.7 & 22.4 & 26.3 \\
\hline & & Standard Deviation & 998 & 853 & 1542 & 692 & 975 \\
\hline
\end{tabular}

Table 6. Normal area under maize in the study districts (in hectares)

\begin{tabular}{|l|l|l|l|}
\hline & Kharif & Rabi & Total \\
\hline Adilabad & 19359 & 7681 & 27040 \\
\hline Karimnagar & 98165 & 48495 & 146660 \\
\hline Nizamabad & 51018 & 9536 & 60554 \\
\hline Warangal & 46085 & 25329 & 71414 \\
\hline Total & 214627 & 91041 & 305668 \\
\hline
\end{tabular}

Source: GoAP, Season and Crop Report, 2009 
Table 7. Normal area under groundnut in the study districts (in hectares)

\begin{tabular}{|l|l|l|l|}
\hline Districts & Kharif & Rabi & Total \\
\hline Adilabad & 0 & 4702 & 4702 \\
\hline Karimnagar & 0 & 14908 & 14908 \\
\hline Nizamabad & 0 & 2351 & 2351 \\
\hline Warangal & 6793 & 29251 & 36044 \\
\hline Total & 6793 & 51212 & 58005 \\
\hline
\end{tabular}

Table 8. Just-Pope function parameters for maize and groundnut

\begin{tabular}{|c|c|c|c|c|}
\hline & \multicolumn{2}{|r|}{ Maize } & \multicolumn{2}{|c|}{ Groundnut } \\
\hline Mean yield & Coefficient & Std.Error & Coefficient & Std.Error \\
\hline Precipitation(R)(in mm) & $1.458^{* * *}$ & 0.624 & -0.140 & 5.488 \\
\hline Temperature $(\mathrm{T})\left(\right.$ in $\left.^{\circ} \mathrm{C}\right)$ & $-1684.180^{* *}$ & 901.492 & $4621.546^{* *}$ & 2272.849 \\
\hline Trend(year) & $73.988^{* * *}$ & 4.854 & $20.096^{* * *}$ & 3.243 \\
\hline $\mathrm{R}^{2}$ & -0.001 & 0.001 & 0.000 & 0.000 \\
\hline $\mathrm{T}^{2}$ & $29.238^{* * *}$ & 7.480 & $-86.010^{* * *}$ & 31.296 \\
\hline $\mathrm{R} * \mathrm{~T}$ & -0.005 & 0.364 & -0.002 & 0.193 \\
\hline Adilabad & $-443.900^{* * *}$ & 117.295 & $-237.896^{* * *}$ & 69.177 \\
\hline Karimnagar & $317.455^{* * *}$ & 123.596 & -40.902 & 71.334 \\
\hline Nizamabad & 168.429 & 149.899 & 78.230 & 130.970 \\
\hline Constant & 24377.590 & 68948.460 & -61385.950 & 40394.420 \\
\hline \multicolumn{5}{|l|}{ Variability in Yield } \\
\hline Precipitation (R) & -0.001 & 0.001 & 0.000 & 0.001 \\
\hline Temperature (T) & $0.133^{*}$ & 0.075 & $0.281^{* *}$ & 0.130 \\
\hline Trend & $0.035^{* *}$ & 0.014 & 0.029 & 0.022 \\
\hline Adilabad & 0.443 & 0.350 & 0.656 & 0.455 \\
\hline Karimnagar & -0.136 & 0.420 & 0.347 & 0.473 \\
\hline Nizamabad & 0.368 & 0.404 & 1.576 & 0.501 \\
\hline Constant & 8.376 & 7.709 & 2.566 & 7.871 \\
\hline Likelihood Fun. & -1182.2 & & -1081.3 & \\
\hline
\end{tabular}


Table 9. Impact of climate change on maize and groundnut yield in Godavari basin $(\mathrm{kg} / \mathrm{ha})$

\begin{tabular}{|c|c|c|c|c|c|c|c|}
\hline Crop & \multirow{2}{*}{$\begin{array}{l}\text { Climate } \\
\text { change } \\
\text { Scenario }\end{array}$} & & $\begin{array}{l}\text { Adilabad } \\
\text { district }\end{array}$ & $\begin{array}{l}\text { Karimnaga } \\
\mathrm{r} \\
\text { district }\end{array}$ & $\begin{array}{l}\text { Nizamabad } \\
\text { district }\end{array}$ & $\begin{array}{l}\text { Waranga } \\
1 \\
\text { district }\end{array}$ & $\begin{array}{l}\text { All } \\
\text { Districts }\end{array}$ \\
\hline \multirow{8}{*}{ 芯 } & & Normal Yield & 3340 & 4185 & 4162 & 3999 & 3922 \\
\hline & & Max-Yield & 3248 & 4010 & 3861 & 3692 & 3703 \\
\hline & $\begin{array}{l}\text { Mid-Century } \\
2.05^{\circ} \mathrm{C} / 13.6 \%\end{array}$ & $\begin{array}{l}\text { MC-Predicted } \\
\text { yield }\end{array}$ & 3249 & 4022 & 3866 & 3687 & 3708 \\
\hline & & $\begin{array}{l}\% \\
\text {-Normal Yield) }\end{array}$ & 2.7 & 3.9 & 7.1 & 7.8 & 5.5 \\
\hline & & Standard Deviation & 785 & 587 & 763 & 667 & 696 \\
\hline & End-Century & EC-Predicted yield & 3321 & 4064 & 3932 & 3788 & 3778 \\
\hline & $4.1^{\circ} \mathrm{C} / 17.8 \%$ & $\begin{array}{l}\% \quad \text { Loss(base } \\
\text {-Normal Yield) }\end{array}$ & 0.6 & 2.9 & 5.5 & 5.3 & 3.7 \\
\hline & & Standard Deviation & 889 & 665 & 865 & 757 & 789 \\
\hline & & Normal Yield & 1344 & 1602 & 1865 & 1412 & 1556 \\
\hline & & Max-Yield & 1203 & 1400 & 1519 & 1441 & 1391 \\
\hline & $\begin{array}{l}\text { Mid-Century } \\
2.05^{\circ} \mathrm{C} / 13.6 \%\end{array}$ & $\begin{array}{l}\text { MC-Predicted } \\
\text { yield }\end{array}$ & 1072 & 1325 & 1394 & 1217 & 1254 \\
\hline 䮍 & & $\begin{array}{l}\% \quad \text { Loss(base } \\
\text {-Normal Yield) }\end{array}$ & 20.2 & 17.3 & 25.2 & 13.8 & 19.4 \\
\hline$\tilde{\Xi}$ & & Standard Deviation & 382 & 319 & 606 & 292 & 383 \\
\hline & End-Century & EC-Predicted yield & 140 & 490 & 485 & 224 & 338 \\
\hline & $4.1^{\circ} \mathrm{C} / 17.8 \%$ & $\begin{array}{l}\% \quad \text { Loss(base } \\
\text {-Normal Yield) }\end{array}$ & 89.6 & 69.4 & 74.0 & 84.1 & 78.3 \\
\hline & & Standard Deviation & 506 & 422 & 802 & 387 & 507 \\
\hline
\end{tabular}


Table 10. Climate change scenarios considered

\begin{tabular}{|c|c|c|c|}
\hline \multirow{2}{*}{$\begin{array}{l}\text { Scenario } \\
\text {-Symbol }\end{array}$} & \multirow[b]{2}{*}{ Description of the Scenario } & \multicolumn{2}{|c|}{ Resource Availability } \\
\hline & & Water $\left(\mathrm{Mm}^{3}\right)$ & $\begin{array}{l}\text { Labour (million } \\
\text { mandays) }\end{array}$ \\
\hline S1 & Current levels of yield, water and labour & $\begin{array}{l}\text { Kharif: } 3110 \\
\text { Rabi: } 1000\end{array}$ & $\begin{array}{l}\text { Kharif: } 2.92 \\
\text { Rabi: } 1.35\end{array}$ \\
\hline S2 & $\begin{array}{l}\text { Current level of yield and } 10 \% \text { reduction in } \\
\text { water and } 5 \% \text { reduction in labour }\end{array}$ & $\begin{array}{l}\text { Kharif: } 2799 \\
\text { Rabi: } 900\end{array}$ & $\begin{array}{l}\text { Kharif: } 2.77 \\
\text { Rabi: } 1.28\end{array}$ \\
\hline S3 & $\begin{array}{l}\text { Projected mid-century yield levels and } 10 \% \\
\text { reduction in water and } 5 \% \text { reduction in labour }\end{array}$ & $\begin{array}{l}\text { Kharif: } 2799 \\
\text { Rabi: } 900\end{array}$ & $\begin{array}{l}\text { Kharif: } 2.77 \\
\text { Rabi: } 1.28\end{array}$ \\
\hline S4 & $\begin{array}{l}\text { Projected end century yield levels and } 10 \% \\
\text { reduction in water and } 5 \% \text { reduction in labour }\end{array}$ & $\begin{array}{l}\text { Kharif: } 2799 \\
\text { Rabi: } 900\end{array}$ & $\begin{array}{l}\text { Kharif: } 2.77 \\
\text { Rabi: } 1.28\end{array}$ \\
\hline
\end{tabular}

Land availability: Kharif: 0.3893 million hectares; Rabi: 0.18 million hectares.

Table 11. Management options considered

\begin{tabular}{|c|c|c|c|}
\hline \multirow{2}{*}{$\begin{array}{c}\text { Management } \\
\text { Option-Symbol }\end{array}$} & \multirow{2}{*}{ Description of the Management Options* } & \multicolumn{2}{|c|}{ Resource Requirements (per ha) } \\
\hline & & Water $\left(\mathrm{m}^{3}\right)$ & Labour (mandays) \\
\hline \multirow{2}{*}{ M1 } & \multirow[t]{2}{*}{ Current management intervention } & Rice: 15520 & Rice: 110 \\
\hline & & Maize: 2280 & Maize: 75 \\
\hline \multirow{2}{*}{ M2 } & \multirow[t]{2}{*}{ System of Rice Intensification (SRI) } & Rice:12416 & Rice: 110 \\
\hline & & Maize:2280 & Maize:75 \\
\hline \multirow{2}{*}{ M3 } & \multirow[t]{2}{*}{ SRI+Machine Transplantng (MT) } & Rice: 12416 & Rice: 93.5 \\
\hline & & Maize:2280 & Maize:75 \\
\hline \multirow{2}{*}{ M4 } & \multirow[t]{2}{*}{ Alternate Wetting and Drying (AWD) } & Rice: 13968 & Rice: 110 \\
\hline & & Maize:2280 & Maize:75 \\
\hline \multirow{2}{*}{ M5 } & \multirow[t]{2}{*}{$\mathrm{AWD}+\mathrm{MT}$} & Rice: 13968 & Rice: 93.5 \\
\hline & & Maize:2280 & Maize:75 \\
\hline \multirow{2}{*}{ M6 } & \multirow[t]{2}{*}{ Maize Water Management (MWM) } & Rice: 15520 & Rice: 110 \\
\hline & & Maize:2052 & Maize:75 \\
\hline \multirow{2}{*}{ M7 } & \multirow[t]{2}{*}{$\mathrm{AWD}+\mathrm{MT}+\mathrm{MWM}$} & Rice: 13968 & Rice: 93.5 \\
\hline & & Maize:2052 & Maize:75 \\
\hline \multirow{2}{*}{ M8 } & \multirow[t]{2}{*}{$\mathrm{SRI}+\mathrm{MT}+\mathrm{MWM}$} & Rice: 12416 & Rice: 93.5 \\
\hline & & Maize:2052 & Maize:75 \\
\hline
\end{tabular}

$* \mathrm{SRI}=20 \%$ reduction in water use; $\mathrm{MT}=15 \%$ reduction in labour; $\mathrm{AWD}=10 \%$ reduction in water use; $\mathrm{MWM}=$ $10 \%$ reduction in water use;

Resource requirement for groundnut under all management options: water: $6880 \mathrm{~m}^{3}$; labour: 78 mandays.

For the third objective, viz., minimizing water use, 4 targets as given in Table 12 for rice production and income were fixed and required quantity of water and labour were derived. 
Table 12. Target levels with minimum water use

\begin{tabular}{|c|l|}
\hline Target & \multicolumn{1}{c|}{ Description } \\
\hline T1 & Current maximum rice production and maximum income \\
\hline T2 & Near future maximum rice production and maximum income \\
\hline T3 & $\begin{array}{l}\text { Near future maximum rice production and maximum income with mid-century climate } \\
\text { change induced productivities }\end{array}$ \\
\hline T4 & $\begin{array}{l}\text { Near future maximum rice production and maximum income with end-century climate } \\
\text { change induced productivities }\end{array}$ \\
\hline
\end{tabular}

Mid-Century-Kharif $\square$ End-Century-Kharif $\square$ Mid-Century-Rabi $\square$ End-Century-Rabi

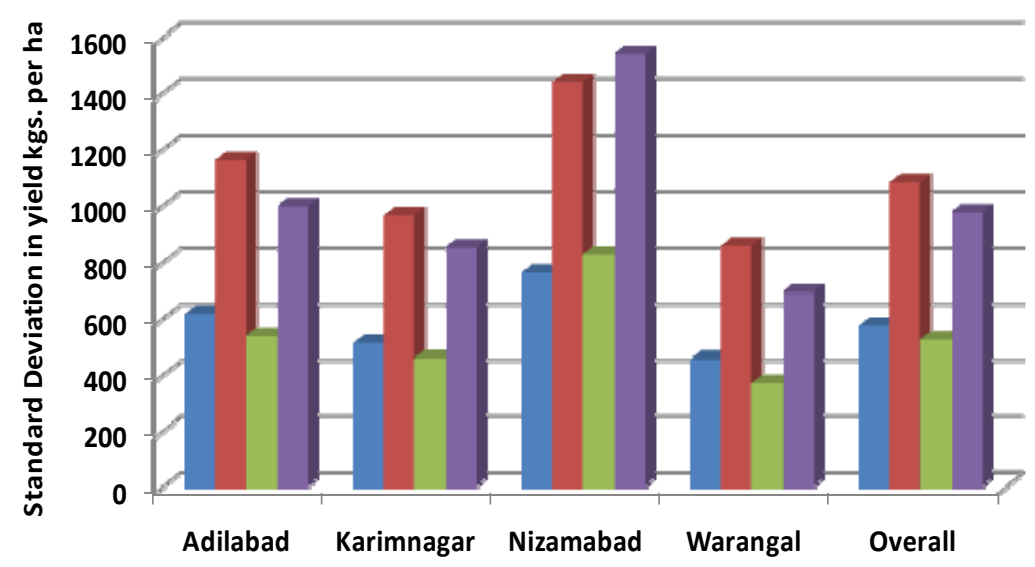

Figure 1. Impact of climate change on variability in yield

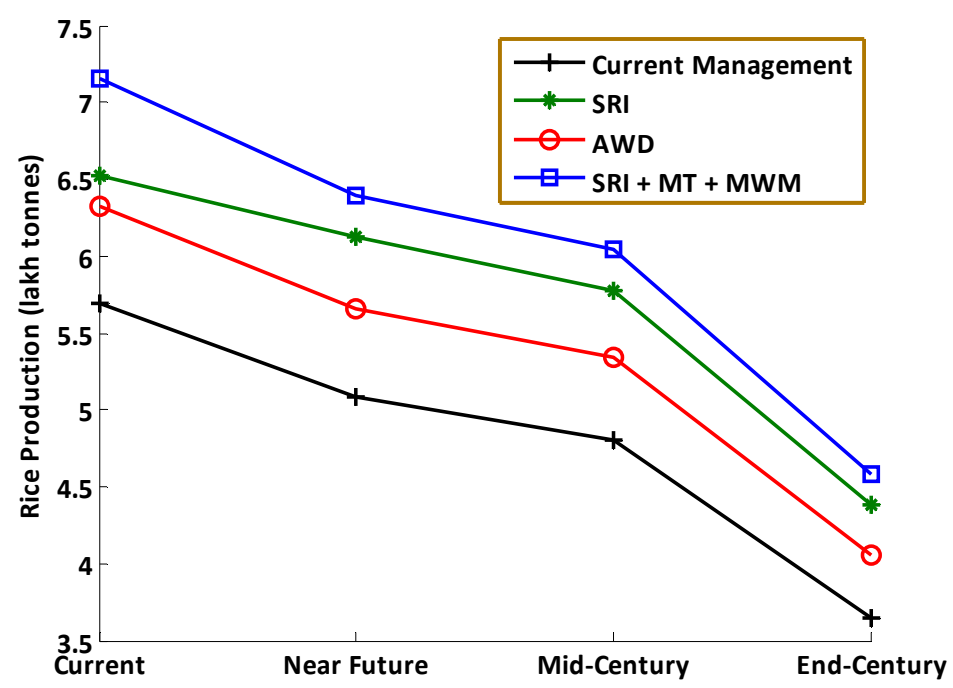

Figure 2. Rice production under different scenarios and management options during Kharif season $(1$ lakh $=100,000)$ 


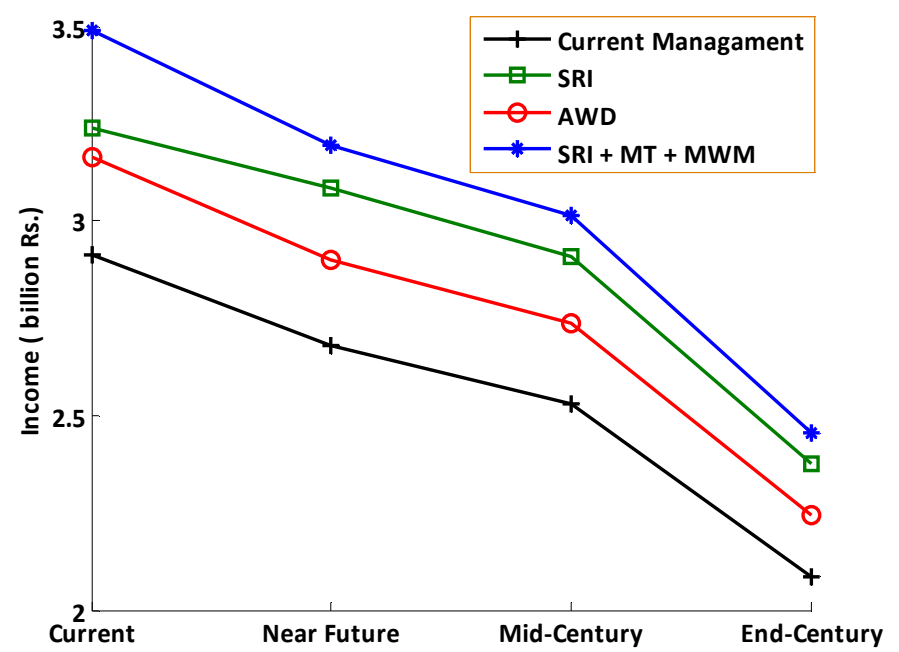

Figure 3. Income under different scenarios and management options during Kharif season

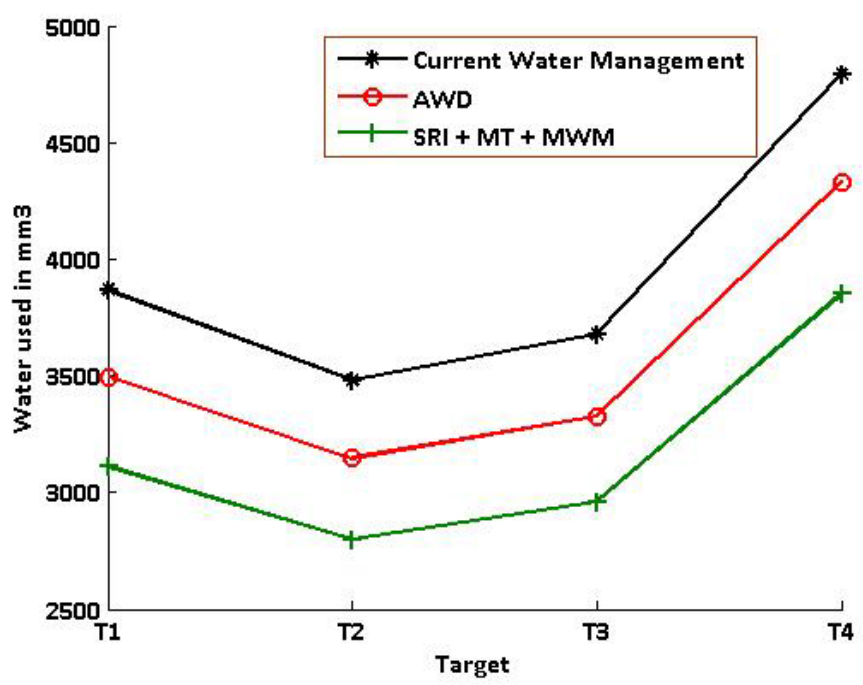

Figure 4. Water use under different scenarios and management options during Kharif season

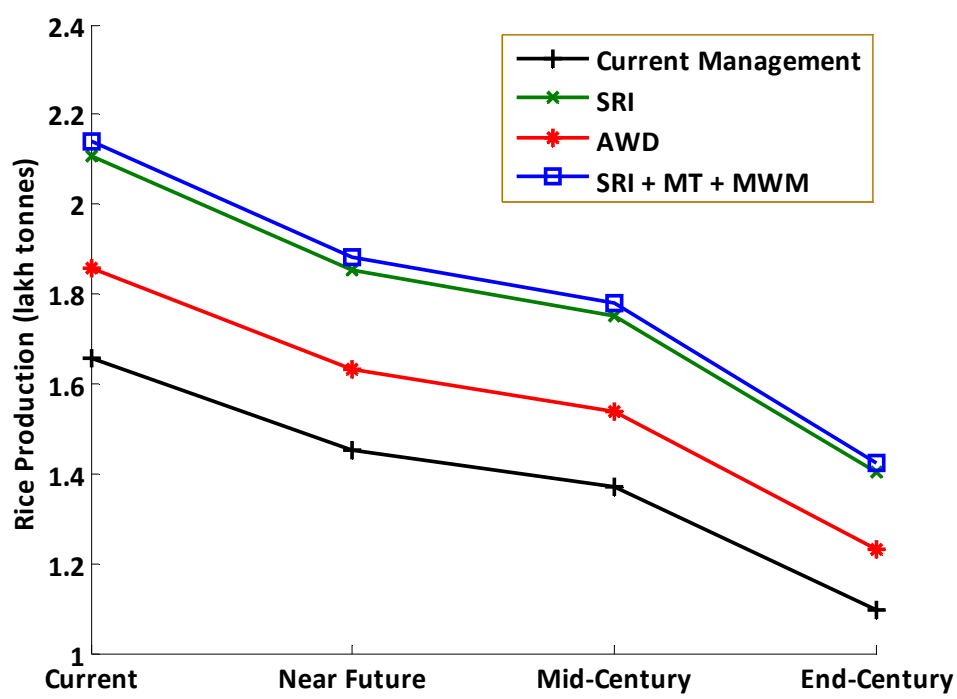

Figure 5. Rice Production under different scenarios and management options during Rabi season 


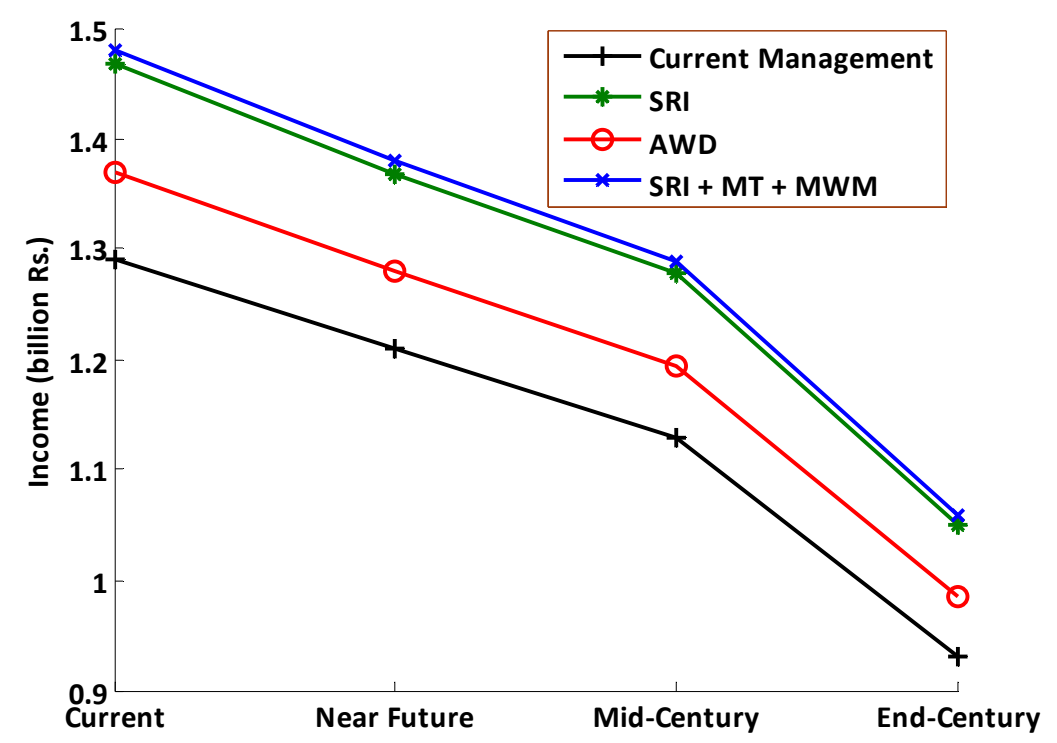

Figure 6. Income under different scenarios and management options during Rabi season

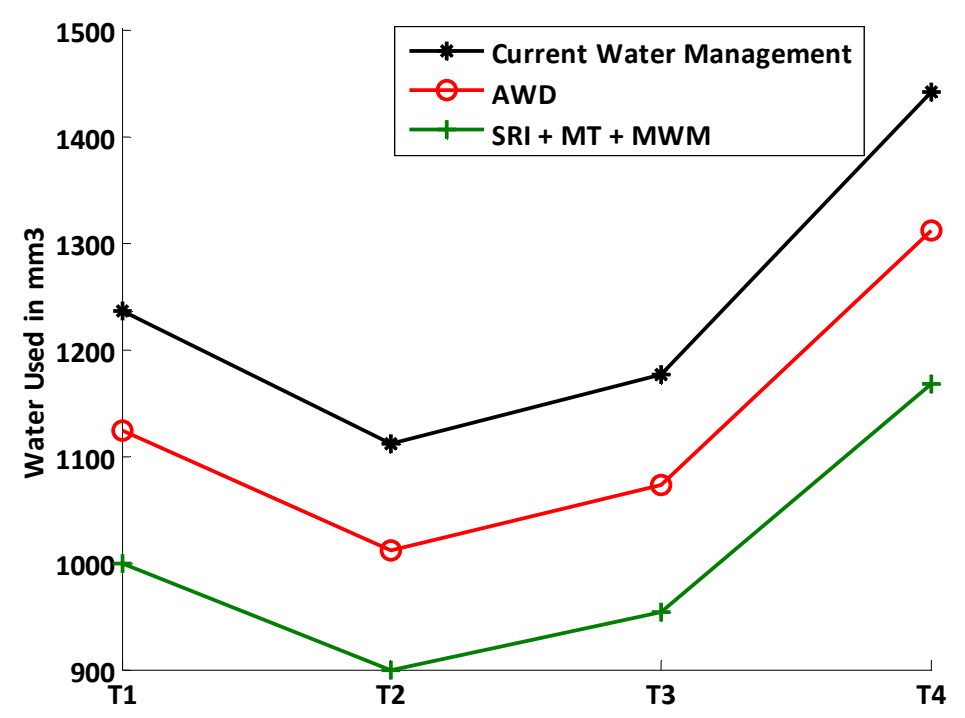

Figure 7. Water Use under different scenarios and management options during Rabi season 